Available online at https://jurnal.stmikroyal.ac.id/index.php/jurdimas

\title{
PENYULUHAN PENDIDIKAN DALAM MENINGKATKAN MINAT SANTRI/WATI UNTUK MELANJUTKAN PENDIDIKAN KE PERGURUAN TINGGI
}

\author{
Iqbal Kamil Siregar ${ }^{1 *}$, Samsul Haq ${ }^{2}$, Nur'ainun Ritonga ${ }^{3}$, Muhammad Ilyas Nst $^{4}$ \\ ${ }^{1}$ Sistem Komputer, Sekolah Tinggi Manajemen Informatika Komputer Royal \\ ${ }^{2}$ Pendidikan Bahasa Arab, UIN Sumatera Utara \\ ${ }^{3}$ Bahasa dan Sastra Arab, Sekolah Tinggi Agama Islam Negeri Mandailing Natal \\ ${ }^{4}$ Ma'had Darul Ikhlash Dalan Lidang Panyabungan \\ email: *iqbalkamilsiregar@ royal.ac.id
}

\begin{abstract}
Educational Counseling in Increasing the Interest of Santri / wati to Continue Education to Higher Education aims to provide knowledge to students about the Higher Education system and the introduction of several campuses and scholarships provided by the government to encourage the government's mission of entrepreneur santri. Of course, the students have different talents and abilities. So it is necessary to have an approach or self-evaluation of what interests will be chosen to continue to higher education. This counseling opportunity becomes an arena to motivate students to continue their education at higher education. He also explained that lectures are not only related to knowledge but also determine the future which will determine a better life. On this occasion the community service team presented various information including describing what study programs and faculties are available. In addition, what is important information is information related to tertiary entry pathways. There are three pathways described, namely the SMPTN, SBMPTN, SPMB, and achievement pathways.
\end{abstract}

Keywords: education; extension; students.

\begin{abstract}
Abstrak: Penyuluhan Pendidikan Dalam Meningkatkan Minat Santri/wati Untuk Melanjutkan Pendidikan ke Perguruan Tinggi bertujuan untuk memberikan pengetahuan kepada santrisantriwati tentang sistem Pendidikan Tinggi dan pengenalan beberapa kampus serta beasiswa yang disediakan pemerintah demi terdorongnya misi pemerintah santri entrepreneur. Para santri tentu memiliki bakat dan kemampuan yang berbeda-beda. Sehingga perlu adanya pendekatan atau evaluasi diri minat apa yang akan dipilih untuk melanjutkan ke perguruan Tinggi. Kesempatan penyuluhan ini menjadi ajang untuk memotivasi para santri untuk bisa melanjutkan pendidikan di perguruan tinggi. Juga menjelaskan bahwa perkuliahan tidak hanya mengejar terkait ilmu tapi menentukan masa depan yang nantinya akan menjadi penentu kehidupan yang lebih baik. Pada kesempatan kali ini tim pengabdian masyarakat memaparkan berbagai informasi diantaranya menjabarkan prodi dan fakultas apa saja yang ada. Selain itu yang menjadi infromasi penting adalah informasi terkait jalur masuk perguruan tinggi. Ada tiga jalur yang dipaparkan yakni jalur SMPTN, SBMPTN, SPMB, dan juga jalur prestasi.
\end{abstract}

Kata kunci: pendidikan; penyuluhan; santri. 
Available online at https://jurnal.stmikroyal.ac.id/index.php/jurdimas

\section{PENDAHULUAN}

Sebelum adanya pembaruan sistem pendidikan, baik oleh kolonial Belanda maupun kaum modernis saat ini, ada beberapa Lembaga Pendidikan yang masih tetap diakui sampai saat ini, yaitu sistem Pendidikan pesantren (Ibrahim, 2014). Sejarah pendidikan Islam di Indonesia juga mencatat bahwa pondok pesantren adalah bentuk lembaga pendidikan tertua di Indonesia yang dapat dikategorikan sebagai pendidikan khas asli Indonesia.

Selain telah berhasil membina dan mengembangkan kehidupan beragama di Indonesia, pondok pesantren juga ikut berperan dalam menanamkan rasa kebangsaan ke dalam jiwa rakyat Indonesia, ikut berperan aktif dalam upaya mencerdaskan kehidupan bangsa, mentransfer ilmu keislaman, memelihara tradisi keislaman, mereproduksi ulama dan mentransmisikan Islam ke dalam kehidupan masyarakat (Stiawan \& Tohirin, 2015).

Sebagai salah satu lembaga pendidikan nonformal, keberadaan Pondok Pesantren menjadi pilar utama menjaga moral dan keberadaban bangsa serta warga negaranya. Moral dan keberadaban ini tidaklah datang dengan sendirinya melainkan dapat ditemukan melalui proses pembelajaran yang terencana, berkelanjutan, berakar pada nilai-nilai agama, kebudayaan nasional Indonesia dan tanggap terhadap tuntutan perubahan zaman (Sujianto, 2012).

Pondok pesantren yang dulunya merupakan sebuah kelompok belajar dengan seorang kyai sebagai pembimbing yang pengajarannya dipusatkan di masjid dan semata-mata mengajarkan ilmu-ilmu agama melalui literatur tradisional berupa kitab-kitab klasik atau kitab kuning dengan proses belajar mengajarnya menggunakan struktur dan metode tradisional pula, yaitu: sorongan, bandongan, wetonan, hafalan, muzarokah tanpa mengenalkan metode pengajaran lainnya, hal tersebut sangat khas sekali dengan ciri-ciri model pendidikan pondok pesantren yang dikategorikan sebagai pondok pesantren salafi (Stiawan \& Tohirin, 2015).

Hal yang sama sampai saat ini masih terus mengalir pada proses Pendidikan yang ada di Sumatera Utara khususnya di Tapanuli Bagian Selatan. Lebih dari 30 pesantren yang ada di Tapanuli Bagian Selatan (Kota Padang Sidimpuan, Kabupaten Tapanuli Selatan, Kabupaten Mandailing Natal, Kabupaten Padang Lawas dan Kabupaten Padang Lawas Utara). Masih setia menjalankan program Pendidikan pesantren tersebut.

Sebagai genarasi muda dan sebagai cikal bakal penerus bangsa Indonesia ini nantinya (Ma'mur \& Christianto, 2020), para santri dan santriwati juga para orang tua kesulitan mengetahui informasi pendidkan maupun beasiswa untuk melanjutkan ke jenjang Pendidikan yang lebih tinggi dan membuat para santri mengurungkan niatnya untuk melanjutkan pendidikan-nya.

Kemajuan suatu bangsa ditentukan oleh kinerja para pendidiknya untuk mengubah karakter generasi penerusnya ke depan. Pencapaian Indonesia hingga saat ini tidak terlepas dari peran seorang guru yang telah membimbing anak muridnya menjadi manusia dewasa dan berperan aktif dalam pembangunan (Fatmah, 2017).

Sebagai alumni tentunya membuat terobosan baru untuk memperkenalkan proses Pendidikan di perguruang tinggi mulai dari pemilihan kampus sampai dengan jurusan/program studi yang bisa dimasuki oleh para santri. 
Available online at https://jurnal.stmikroyal.ac.id/index.php/jurdimas

Berdasarkan informasi yang diperoleh dan berdasarkan pengalaman selama jadi santri di Ma'had Darul Ikhlas Dalan Lidang Panyabungan, sulitnya santri/wati mendapatkan informasi tentang perguruan Tinggi dalam dan Luar Negeri, belum adanya terlintas bagimana kehidupan yang ada di dunia kampus, serta proses pemilihan jurusan dan pemilihan kampus sesuai dengan kemampuan santri/santriwati.

Maksud dari kegiatan pengabdian ini adalah melaksanakan Tri Dharma Perguruan Tinggi berupa Pengabdian Kepada Masyarakat sebagai pengamalan ilmu pengetahuan, teknologi kepada santri/wati Ma'had Darul Ikhlas Dalan Lidang Panyabungan. Tujuan yang ingin di capai dalam kegiatan ini adalah memberikan informasi Pendidikan Dalam Meningkatkan Minat Santri/wati Untuk Melanjutkan Pendidikan ke Perguruan Tinggi sehingga dapat meningkatkan antusias atau motivasi bagi para santri untuk melanjutkan pendidikan ke jenjang yang lebih tinggi. Manfaat kegiatan pengabdian kepada Masyarakat diharapkan dapat menjadi suatu kegitan yang rutin dilakukan untuk memberikan info yang up to date tentang pendidikan tinggi. Serta Memberikan informasi terbarukan tentang perguruan tinggi dalam maupun luar negeri serta jurusan yang langka peminat sehingga, pengabdian masyarakat ini dilaksanakan untuk memberikan pengetahuan dalam bentuk penyuluhan pendidikan dalam meningkatkan minat santri/wati untuk melanjutkan pendidikan ke perguruan tinggi. Target pengabdian ini adalah para santri/wati untuk mendaptkan informasi lebih tentang dunia Pendidikan diluar pesantren. Kondisi sekolah/ pesantren maupun santri/ wati yang akan dijadikan tempat pengabdian dapat dilihat pada gambar 1. Ma'had Darul Ikhlas yang be- rada dikabupaten Mandailing Natal mempunyai 2 tingkatan pendidikan, mulai dari Madrasah Tsanawiyah setingkat SMP hingga Mandrasah Aliyah setingkat SMA.

\section{METODE}

Metode yang dilakukan dalam pelaksanaan pengabdian masyarakat ini dengan konsep penyuluhan Pendidikan yang dilakukan secara sistematik, terencana dan terarah. Metode penyampaian pesan dalam kegiatan penyuluhan merupakan faktor yang sangat menentukan keberhasilan (Nurdin, 2014).

Dengan metode penyampaian langsung baik kepada santri/wati Ma'had Darul Ikhlas dengan jumlah peserta 45 orang. kegiatan dilakukan dengan satu acara dengan dua sesi. Pertama, penyampaian informasi dan motivasi secara bertahap kepada santri. Kedua, acara yang sama juga dilakukan kepada santriwati. Pelaksanaan dilakukan secara langsung dengan menjelaskan manfaat melanjutkan Pendidikan ke jenjang yang lebih tinggi hingga kampus atau Perguruan Tinggi yang ada di Kota-kota besar.

\section{PEMBAHASAN}

Pesantren merupakan pendidikan islam tertua di Indonesia yang menjunjung tinggi pengetahuan dan penanaman moral agama islam sebagai acuan pedoman dalam kehidupan sehari-hari. Pesantren juga merupakan aset pendidikan genuine bangsa Indonesia yang mampu bertahan hidup di tengah terpaan angin modernitas (Hasanah, 2017).

Sesuai dengan rencana dan proses yang telah dilaksanakan bahwa pengabdian masyarakat mengenai tema 
Available online at https://jurnal.stmikroyal.ac.id/index.php/jurdimas

"Penyuluhan Pendidikan Dalam Meningkatkan Minat Santri/wati Untuk Melanjutkan Pendidikan ke Perguruan Tinggi" yang dilaksanakan di Ma'had Darul Ikhlas Dalan Lidang Panyabungan, maka kegiatan tersebut telah direalisasikan sesuai dengan rencana dan berjalan dengan lancar dan efektif. Hal ini dikarenakan banyaknya dukungan dari berbagai pihak baik STMIK Royal Kisaran melalui LPPM, pihak Ma'had Darul Ikhlas, serta Mudir Ma'had, ustadz dan staf pegawai Madrasah dan rekan-rekan dari Himpuan Abituren Ma'had Darul Ikhlas (HAMDI) Sumatera Utara. Adapun kegiatan pengabdian ini dimulai pada tanggal 6 Januari hingga 24 Maret 2020, pelaksanaan penyuluhan tangal 01-02 Februari 2020 mulai pukul 08.00 WIB s/d selesai.

Dari hasil penyuluhan yang telah dilakukan kepada santri/wati Ma'had Darul Ikhlas Dalan Lidang Panyabungan tersebut di atas telah dirasakan sangat bermanfaat. Hal ini berdasarkan hasil bincang-bincang dengan pihak ma'had dan santri/wati yang telah selesai menjalani penyuluhan ingin melanjutkan pendidikannya ke Perguruan Tinggi. Keberhasilan ini juga didasari dari testimoni Mudir Ma'had dan para ustadz beserta staf Ma'had Darul Ikhlas Dalan Lidang Panyabungan yang menyampaikan bahwa kegiatan penyuluhan ini harus dibuat secara continue guna untuk meningkatkan minat santri/wati untuk melanjutkan Pendidikan ke perguruan tinggi.

Mudir atau pimpinan mengatakan kedatangan tim pengabdian masyarakt tersebut sangat bermanfaat untuk mendorong sebanyak-banyaknya para santri dan santriwati bisa melanjutkan pendidikannya ke perguruan tinggi.

Adapun hasil yang didapat adalah bertambahnya pengetahuan dan informasi yang didapat oleh santri/wati tentang Pendidikan tinggi baik jurusan maupun beasiswa yang disediakan pemerintah maupun pihak swasta, dibuktikan dengan meningkatnya jumlah santri/wati yang sudah melanjutkan pendidikannya khususnya di Uniersitas Islam Negeri (UIN) Sumatera Utara dan juga berbagai kampus lain di Sumatera Utara.

Selesainya kegiatan pengabdian masyarakat yang dilakukan oleh tim pengabdian STMIK Royal dibuktikan dengan laporan pengabdian.

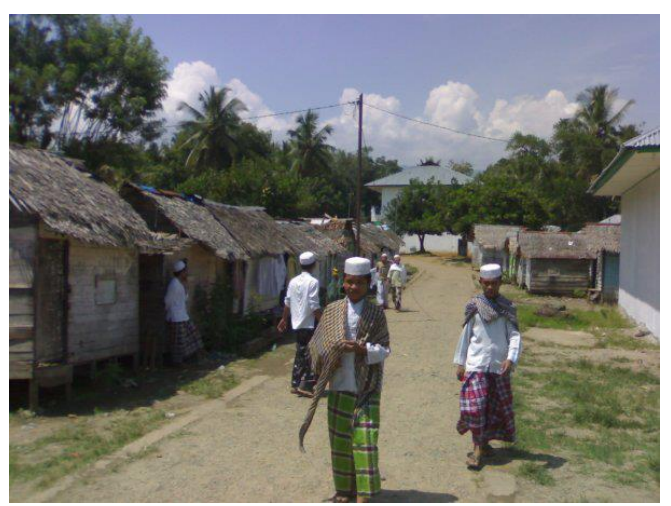

\section{Gambar 1. Lokasi Santri Darul Ikhlas}

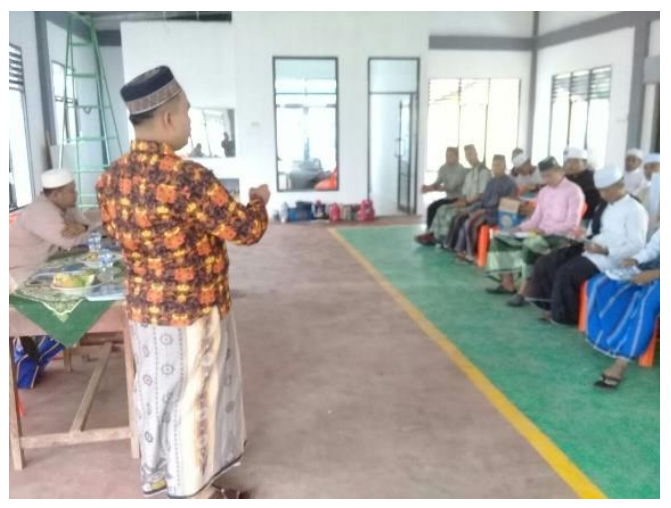

Gambar 2. Penyampaian Materi Kepada Santri 


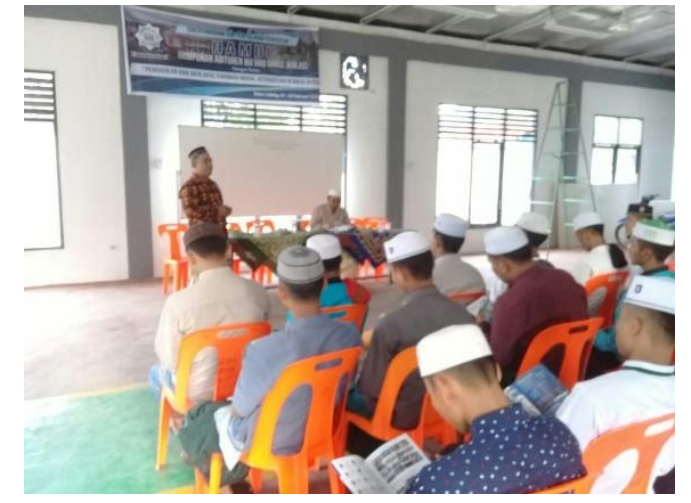

Gambar 3. Penyampaian Materi Kepada Santri

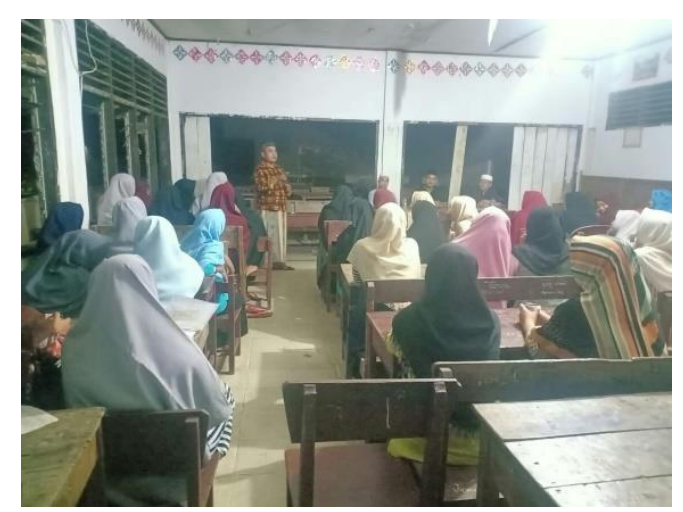

Gambar 4. Penyampaian Materi Kepada Santriwati

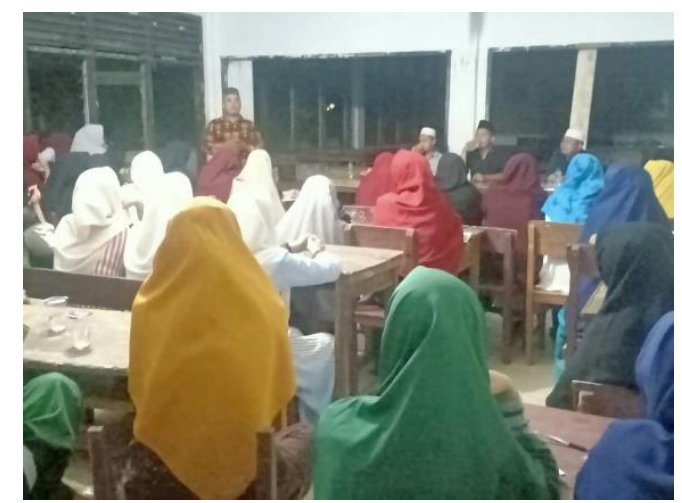

Gambar 5. Penyampaian Materi Kepada Santriwati

\section{SIMPULAN}

Hasil dari Kegiatan Pengabdian Masyarakat ini dapat memberikan manfaat bagi Ma'had Darul Ikhlas Dalan
Lidang Panyabungan khususnya santri /wati kelas 3 (tiga) Aliyah yang mau diwisuda di tahun ini, serta membantu Pimpinan maupun Ustadz-Ustadzah sudah terbantu untuk mendorong niat dan memotivasi santri/wati untuk melanjutkan Pendidikan ke jenjang yang lebih tinggi. Dengan adanya penyuluhan ini diharapkan dapat meningkatkan minast belajar dan kreatif siswa Ma'had Darul Ikhlas Dalan Lidang Panyabungan untuk lebih giat dalam belajar.

\section{UCAPAN TERIMA KASIH}

Ucapan terimakasih di sampaikan kepada Mudir selaku direktu atau manager, serta para Ustadz dan Ustadzah Ma'had Darul Ikhlas yang telah memberikan kesempatan kepada Tim Pengabdian untuk menyampaikan materi penyuluhan Pendidikan. Serta ucapan terimakasih di sampaikan kepada bapak Ketua Yayasan Pendidikan Royal Teladan Asahan, Ibu Ketua STMIK Royal Kisaran, serta bapak Ibu Dosen.

\section{DAFTAR PUSTAKA}

Fatmah, D. (2017). Penyuluhan Meningkatkan Kinerja Guru Melalui Etos Kerja Spiritual Islamiyah.

Hasanah, K. N. S. (2017). Bimbingan Keagamaan di Pesantren untuk Meningkatkan Kemampuan Beragama Santri. Irsyad: Jurnal Bimbingan, Penyuluhan, Konseling, Dan Psikoterapi Islam, 5(4), 407-430.

Ibrahim, R. (2014). Eksistensi Pesantren Salaf di Tengah Arus Pendidikan Modern. Analisa, 
Available online at https://jurnal.stmikroyal.ac.id/index.php/jurdimas

21(2),

253. https://doi.org/10.18784/analisa. v21i02.19

Ma'mur, K. Christianto, W. (2020). Penyuluhan Tentang Pemanfaatn Internet Yang Aman dan Baik Bagi Santri Pondok Pesantren Darul Islah. Penyuluhan Tentang Pemanfaatn Internet Yang Aman Dan Baik Bagi Santri Pondok Pesantren Darul Islah, $\quad 1(1), \quad 115-$ 121.http://openjournal.unpam.ac .id/index.php/JAMAIKA/article/ view/4494

Nurdin, N. (2014). Pengaruh Metode Penyuluhan Dan Tingkat Pendidikan Terhadap Pengetahuan Berwawasan Lingkungan. Jurnal Ilmu Pendidikan Universitas Negeri Malang, 20(2), 107049.

Saputra, N., A'la Al Maududi, A., \&
Sadiah, N. A. (2020). Penyuluhan Kesehatan Pencegahan Penyakit Tuberkulosis dan Pengobatan Gratis Di Pesantren Sabilunnajat. AS-SYIFA: Jurnal Pengabdian dan Pemberdayaan Kesehatan Masyarakat, 1(1), 37-40.

Stiawan, K., \& Tohirin, D. M. (2015). Format Pendidikan Pondok Pesantren Salafi dalam arus Perubahan Sosial di kota Magelang. Cakrawala, X(2), 194-209.

Sujianto, A. E. (2012). Pengaruh Pendidikan, Pelatihan dan Penyuluhan Terhadap Partisipasi Anggota Koperasi Pondok Pesantren. Inferensi, 6(2), 325. https://doi.org/10.18326/infs13.v 6i2.325-348 